\title{
Comparison of two preparatory techniques for urine cytology
}

\author{
J Dhundee, H S Rigby
}

\begin{abstract}
Two methods of preparation of urine for cytology were compared retrospectively. In method 1 cells in the urine were fixed after the preparation of the smear; in method 2 the cells were fixed before smear preparation. Urine cytology reports were correlated with subsequent histological analysis. The specificities of urine cytology using both methods were high $(99 \%)$. The sensitivity using method 1 was $87 \%$; using method 2 it was $65 \%$. This difference was significant. The cell preparation technique therefore significantly changes the sensitivity of urine cytology. Cellular fixation after smear preparation is preferable to smear preparation after fixation.
\end{abstract}

The importance of urine cytology for the detection of urological malignancy is well established. ${ }^{1-4}$ Exfoliated cells in a urine sample, especially single cells, deteriorate rapidly and degenerative changes are seen within one hour. ${ }^{5}$ To permit optimal visualisation of the sample it is important, therefore, to have a high yield of well preserved cells, and to achieve this a variety of methods have been used. ${ }^{6-10}$

This retrospective study compares a method in which the cells are spray fixed after the smear is made with one in which fixation is undertaken before smearing.

\section{Methods}

All urine cytology reports for two six month periods were retrieved from the computer based files and compared. In the last six months of 1987 the specimens were fixed after the smear was made (method 1); in the last six months of 1988 the cells were fixed before smear preparation (method 2).

\section{METHOD 1}

Specimens were received in a bottle containing $5 \mathrm{ml}$ of absolute alcohol which slows down bacterial growth when added to freshly voided urine. The entire sample was centrifuged at $1500 \mathrm{rpm}$ for five minutes using an MSE Centaur 2 Centrifuge and the supernatant decanted. The deposit was then cytocentrifuged using a Shandon Cytospin 2 at 1200 rpm for five minutes.

The cells on the slide were then spray fixed using $80 \mathrm{ml}$ polyethylene-glycol, $690 \mathrm{ml}$ Isopropanol, $170 \mathrm{ml}$ acetone and $60 \mathrm{ml}$ distilled water. Atter a minımum of tive minutes' drying time the preparation was stained with
Papanicolaou's technique using a Shandon Linistain GLX.

\section{METHOD 2}

The samples were received in an identical manner with that described in method 1 . The entire sample was centrifuged at $1500 \mathrm{rpm}$ for five minutes using an MSE Centaur 2 Centrifuge and the supernatant decanted. Fixative $(5 \mathrm{ml})(25 \mathrm{ml}$ glacial acetic acid, $20 \mathrm{ml}$ methanol, $105 \mathrm{ml}$ distilled water) was then added to the deposit of cells, mixed well, and allowed to stand for 30 minutes. The sample was respun, the supernatant decanted, and the sample processed in the cytospin (Shandon Cytospin 2 ) as in method 1. The slides were allowed to dry for two to three minutes and the preparation stained in an identical manner with that described in method 1.

When haematuria was suspected, a wet preparation was made to look for red blood cells.

\section{CALCULATION OF RESULTS}

The cytological diagnoses were correlated with the final histological diagnoses using interlinked computed records. The reports of urine preparations were divided into the following categories:

1 Positive cytology-this was subdivided into two subgroups clearly malignant and suspicious of malignancy.

2 Negative cytology-urine samples where no malignant cells were seen.

3 Inadequate specimen-any specimen in which the preparation was obscured by polymorphs, crystals, bacteria, squames, spermatozoa, or was poorly cellular, or consisted of degenerate cells.

\section{Results}

Between July 1987 and December 1987 a total of 372 urine samples were examined. Of these samples, $297(80 \%)$ were reported as negative, $30(8 \%)$ as inadequate, $17(5 \%)$ were suspicious of malignancy, and $28(7 \%)$ were clearly malignant. These represented 248 patients with negative cytology, 17 patients with suspicious cytology, and 23 patients with clearly malignant cytology. Four of the 248 $(1.6 \%)$ patients with negative cytology were subsequently found to have a malignancy. Review of the urine samples from these four patients showed that two had highly atypical cells on review and two had no suspicious cytological features. Ten of the $17(59 \%)$ patients with suspicious samples were subsequently found to have histologically confirmed malignancy. 
Between July 1988 and December 1988 a total of 507 urine samples were processed. Of these samples, $369(73 \%)$ were negative, 87 $(17 \%)$ were inadequate, $10(2 \%)$ were suspicious of malignancy, and $41(8 \%)$ had clearly malignant cytology. These represented 304 patients with negative cytology, nine patients with suspicious cytology, and 34 patients with clearly malignant cytology. Twenty of the 304 $(6.6 \%)$ patients with negative cytology were subsequently found to have a malignancy. Review of these false negative cases showed that eight cases did have atypical cells amounting to suspicious features, four cases had unsatisfactory specimens, and eight had no malignant or suspicious features. Seven out of nine $(78 \%)$ patients with suspicious samples were subsequently found to have a malignancy.

Tables 1 and 2 show the results based on the histological analysis of the subsequently diagnosed urinary tract lesions. Of the 31 patients with confirmed malignancy, 27 were correctly identified by urine cytology processed using method 1 , resulting in a sensitivity of $87 \%$.

Of the 57 patients with confirmed malignancy, 37 were correctly identified by urine cytology processed using method 2 , resulting in a sensitivity of $65 \%$. Analysis showed a significant difference $\left(\chi^{2}=5.08\right.$ when $\left.p<0.05\right)$ between the sensitivities of the two methods. The specificity of urine cytology was the same $(99 \%)$ using both methods of smear preparation.

\section{Discussion}

This study shows that the method of smear preparation significantly affects the sensitivity of urine cytology in the detection of urinary tract malignancy. The overall sensitivity of urine cytology in this laboratory was $78 \%$. This is comparable with sensitivities shown in other studies $(77 \%){ }^{11}$ The specificity of urine cytology using both methods of smear preparation was high $(99 \%)$.

All abnormal cytological preparations were seen by one cytopathologist for both methods-at the initial assessment and at subsequent review. In addition, there was no change in the pattern of referral by clinicians that could have accounted for the differences in sensitivities of the two methods.

There are several possible explanations for the reduced sensitivity of method 2 . In method 1 the fixative is sprayed over a thin smear of dispersed cells; in method 2 the cells are fixed before smear preparation. This may result in poor penetration of the fixative fluid to the centre of the deposit. In addition, the fixative in
Table 2 Results of urine cytology and subsequent histological analysis

\begin{tabular}{llllll}
\hline & \multicolumn{2}{l}{ Histology } & & \multicolumn{2}{l}{ Non-malignant } \\
\cline { 2 - 3 } \cline { 5 - 6 } Cytology & \multicolumn{2}{l}{ Malignant } & & & \\
\cline { 2 - 3 } \cline { 5 - 6 } Method 1 & Method 2 & & Method 1 & Method 2 \\
\hline Malignant & 17 & 30 & & 0 & 0 \\
Suspicious & 10 & 7 & & 1 & 2 \\
Non-malignant & 4 & 20 & 244 & 284 \\
Total & 31 & 57 & 245 & 286 \\
\hline
\end{tabular}

method 2 may result in changes in cytological morphology to which malignant cells may be more susceptible. There is reduced aherence of prefixed cells to the slides, which causes loss of cells and a reduced yield. ${ }^{12}$ Indeed, in the method described by Esposti ${ }^{4}$ an adhesive is used which is not used in method 2 . These factors are implicated in the increased numbers of urine preparations reported as inadequate using method 2 (8\% with method $1 ; 17 \%$ with method 2). In method 2 the proportion of samples reported as suspicious of malignancy decreased when compared with those of method 1 ( $5 \%$ with method $1 ; 2 \%$ with method 2). We postulate that this is due to specimens prepared using method 2 being reported as inadequate. This is associated with a rise in the number of false negative cases using method 2 .

In conclusion, we have found that the method of smearing the urinary cellular deposit followed by spray fixation provides superior sensitivity over that of smearing fixed cells.

We are grateful to Dr EFD Mackenzie for advice, Mrs F Adamson for technical assistance, Dr P Protheroe for statistical assistance, and Mrs E Rogers for typing the manuscript.

1 Crabbe JGS, Cresdee WC, Scott TS, Williams MHC. The cytological diagnosis of bladder tumours amongst dyestuff cytological diagnosis of bladder tumours amc

2 Crabbe JGS. Cytology of voided urine with special reference to "benign" papilloma and some of the problems encountered in the preparation of the smears. Acta Cytol 1961; 5:233-40.

3 Trott PA. Cytological screening for cancer of the bladder. Proc Roy Soc Med 1976;69:496-8.

4 Esposti PL, Moberger G, Zajicek J. The cytological diagnosis of transitional cell tumours of the urinary bladder and its histological basis. Acta Cytol 1970;14:145-55.

5 Beyer-Boon ME. Preparatory techniques In: The efficacy of urinary cytology. Delft: WD Meinema, 1977:46-53.

6 Trott PA. Cytological examination of urine using a membrane filter. Br J Urol 1967;39:610-4.

7 Barrett DL, King EB. Comparison of cellular recovery rates and morphologic detail obtained using membrane filter and cytocentrifuge techniques. Acta Cytol 1976;20: and cytoce.

8 Beyer-Boon ME, Voorn-den Hollander MJA. Cell yield obtained with various cytopreparatory techniques for obtained with various cytopreparatory tech
urinary cytology. Acta Cytol 1978;22:589-94.

9 Beyer-Boon ME, Arentz PW, Kirk RS. A comparison of thiomersal and $50 \%$ alcohol as preservatives in urinary cytology. J Clin Pathol 1979;32:168-70.

10 Boccato P. Modification of Fischer's method for urine cytology. Acta Cytol 1981;25:5-6.

11 Kern WH. The diagnostic accuracy of sputum and urine cytology. Acta Cytol 1988;32:651-4.

12 Beyer-Boon ME. Smear preparation techniques In: Urinary cytology. HJ de Voogt, ME Beyer-Boon, P Rathert, eds. Berlin: Springer, 1977:9-13.

Table 1 Details of histological analysis after cytological examination

\begin{tabular}{|c|c|c|c|c|c|c|c|c|}
\hline \multirow[b]{3}{*}{ Histological diagnosis } & \multirow{2}{*}{\multicolumn{2}{|c|}{ No of cases }} & \multicolumn{6}{|c|}{ Cytological classifications } \\
\hline & & & \multicolumn{2}{|l|}{ Negative } & \multicolumn{2}{|l|}{ Suspicious } & \multicolumn{2}{|l|}{ Positive } \\
\hline & Method 1 & Method 2 & Method 1 & Method 2 & Method 1 & Method 2 & Method 1 & Method 2 \\
\hline $\begin{array}{l}\text { Transitional cell carcinoma } \\
\text { Transitional cell carcinoma in situ } \\
\text { Anaplastic carcinoma } \\
\text { Renal adenocarcinoma } \\
\text { Vulval carcinoma } \\
\text { Calculous cystitis } \\
\text { Urothelial inflammation } \\
\text { Glomerulonephritis }\end{array}$ & $\begin{array}{r}26 \\
4 \\
0 \\
1 \\
0 \\
1 \\
0 \\
0\end{array}$ & $\begin{array}{r}49 \\
5 \\
1 \\
1 \\
1 \\
0 \\
1 \\
1\end{array}$ & $\begin{array}{l}4 \\
0 \\
0 \\
0 \\
0 \\
0 \\
0 \\
0\end{array}$ & $\begin{array}{r}20 \\
0 \\
0 \\
0 \\
0 \\
0 \\
0 \\
0\end{array}$ & $\begin{array}{l}8 \\
1 \\
0 \\
1 \\
0 \\
1 \\
1\end{array}$ & $\begin{array}{l}6 \\
0 \\
0 \\
1 \\
0 \\
0 \\
1 \\
1\end{array}$ & $\begin{array}{r}14 \\
3 \\
0 \\
0 \\
0 \\
0 \\
0 \\
0\end{array}$ & $\begin{array}{r}23 \\
5 \\
1 \\
0 \\
1 \\
0 \\
0 \\
0\end{array}$ \\
\hline
\end{tabular}

